\title{
Køns betydning for lokalaftaler om ligeløn og familie-arbejdsliv
}

Af Trine P. Larsen

Under de seneste års overenskomstforbandlinger har familie-arbejdslivsbalancer og ligelon veret centrale temaer. Men det er primart det første tema, som optager parterne på virksombederne - og interessant nok er det oftere en mandlig end en kvindelig TR, som er initiativtageren.

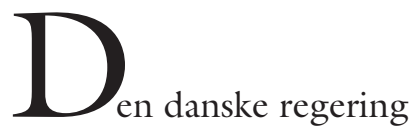

og arbejdsmarkedets parter har i de senere år stået i spidsen for forskellige tiltag for at fremme ligeløn på arbejdsmarkedet og lette lønmodtageres familie/arbejdslivsbalance. Spørgsmålet er imidlertid, om initiativerne er slået igennem på arbejdspladsniveau.

Med udgangspunkt $i$ en undersøgelse med tillidsrepresentanter (TR) på LO-området belyser denne artikel, i hvilken grad tiltag om ligeløn mellem kønnene og familie-arbejdslivsbalancer som fx flekstidsordninger, fuld løn under fædreorlov og børns sygdom drøftes og forhandles på kvindeog mandsdominerede arbejdspladser. Det undersøges om rammebetingelserne, som fx TR's køn, arbejdspladsens kønsfordeling, mulighederne for lokalforhandling og forholdet mellem ledelsen og TR, har betydning for, hvad der optager parterne lokalt. Artiklen bidrager dermed med ny viden indenfor et område, hvor fă studier eksplicit har belyst de tiltag, som parterne har udviklet indenfor det virksomhedsbaserede afta- 
lesystem for at fremme ligeløn og familiearbejdslivsbalancer (Rigby og Smith 2010).

Artiklen viser, at familie-arbejdslivsbalancer ofte står øverst på virksomhedernes dagsorden, mens ligeløn sjældent optager parterne lokalt. Det er især arbejdspladser med lige mange mænd og kvinder, hvor disse emner drøftes, forhandles og udmunder i konkrete aftaler - og interessant nok er det på den type arbejdspladser ofte en mandlig TR, der tager initiativet. Resultaterne er særligt interessante, idet familie-arbejdslivs- og ligeløns-problematikken ofte indenfor litteraturen associeres med kvinder. Det kunne derfor forventes, at emnerne ville være mere udbredt på de kvindedominerede arbejdspladser - og at særligt kvindelige TR'ere ville tage initiativ til at drøfte emnerne og lave aftaler (Emerek og Bloksgaard 2010).

I artiklen beskrives først kort de seneste tiltag om ligeløn og familie-arbejdsliv. Dernæst udvikles en analyseramme for den videre analyse af, hvordan ligeløns- og familie-arbejdslivstiltag drøftes og forhandles lokalt.

\section{LIGELØNS- OG \\ FAMILIE-ARBEJDSLIVSTILTAG}

Regeringen og arbejdsmarkedets parter har iværksat en række initiativer for at fremme ligeløn og lette lønmodtageres balanceproblemer. Seneste regeringsudspil er handlingsplanen: Redegorelse, perspektiv og handlingsplan fra 2012, som bl.a. sigter på at undersøge mulighederne for at udbygge den kønsopdelte lønstatistik. En del af handlingsplanen er også øremærkning af op til tre måneder af den betalte barselsperiode til mænd og etableringen af en obligatorisk barselsudligningsfond for selvstændige ( $\mathrm{Mi}$ nisteriet for ligestilling og kirke 2012). Ligelønskommissionen fra 2010 og Familiearbejdslivskommissionen fra 2006 er også eksempler på regeringsdrevne initiativer, der sigter på at kortlægge lønforskelle mellem mænd og kvinder samt lønmodtageres balanceproblemer. Loven om kønsopdelt lønstatistik og redegørelse om ligeløn, som trådte i kraft i 2007, barselsudligningsfonden fra 2006 og ret til fravær fra arbejde af særlige familiemæssige årsager fra 2006 er nogle af de seneste lovkrav på de to områder.

Danske fagforeninger og arbejdsgiverorganisationer har også udviklet forskellige ligeløns- og familie-arbejdslivstiltag indenfor rammerne af det kollektive aftalesystem, hvor løn og arbejdsvilkår i vid udstrækning reguleres gennem overenskomster frem for lovgivning. Overenskomsterne er på nogle områder forud for lovgivningen, og især de offentlige overenskomster tilbyder mere vidtgående rettigheder mht. løn under barsel, omsorgsdage og børns sygdom end det, loven foreskriver. Den private sektor er dog kommet relativt godt med. Overenskomstforliget for 2012 indenfor fx bank og forsikringssektoren indeholder tiltag som øget frihed ved børns sygdom og ret til deltid (FA 2012). På industriens område blev CO-industri og DI i 2012 enige om en mere fleksibel forældreorlov, mens deres overenskomstforlig fra 2010 bl.a. indeholdt øremærkning af to ugers barsel til fædre, barnets anden sygedag og nedsættelse af et ligelønsnævn, som skal behandle ligelønssager og sætte nyt fokus på lønforskellen mellem kønnene. Indenfor brancher som fx transport, handel, restauration og service er rettighederne til fx betalt barselsorlov og frihed ved børns sygdom mindre gunstige (HK-handel 2010). Parterne har endvidere publiceret pamfletter, undersøgelser, kampagner og strategier om ligeløn og familiearbejdslivsbalancer.

Spørgsmålet er dog, om tiltagene slår igennem på arbejdspladsniveau, hvilket synes vigtigt i et aftalesystem som det danske, hvor forhandlinger om detaljer i overenskomsterne i stadig større grad flyttes ud på arbejdspladserne. Det er op til parterne lokalt at drøfte, udfylde og omsætte overenskomsternes bestemmelser til praksis (Due og Madsen 2008). På nogle arbejdspladser 
kan TR og arbejdsgiverne endvidere indgå mere vidtgående aftaler, som afviger fra de centrale overenskomster, såfremt der er enighed herom (Ilsø 2011). Dette gxlder fx indenfor industriens område, mens andre overenskomster som $\mathrm{fx}$ indenfor handel og kontor giver mindre rum for afvigelser fra de centrale overenskomster. Ift. ligelønsog familie-arbejdslivsområdet giver nogle lokalaftaler fx ret til barnets anden eller flere sygedage eller indeholder retningslinjer for ligelønsredegørelser (Holt og Larsen 2011).

\section{LIGELØN OG FAMILIE/ARBEJDSLIVS- BALANCER I OVERENSKOMSTSYSTEMET}

Et væld af danske og internationale studier har belyst ligeløns- og familie-arbejdslivsproblematikken. Fokus er dog sjældent på, hvordan sådanne emner drøftes og forhandles lokalt på virksomhederne indenfor aftalesystemets rammer (Ravenswood og Markey 2011). De få studier, som belyser sådanne tiltag, viser bl.a. markante forskelle mellem offentlige og private arbejdspladser samt forskelle på mands- og kvindedominerede arbejdspladser (Rigby og Smith 2010). Ordningerne på kvindedominerede arbejdspladser og indenfor det offentlige fremhrves fx som mere generøse i Danmark (Emerek og Bloksgaard 2010).

De nævnte studier beskæftiger sig endvidere i varierende grad med fagforeningens rolle. Nogle studier fremhæver vigtigheden af en kvindelig fagforeningsrepræsentant for, at ligeløns- og familie-arbejdslivstiltag kommer på dagsorden (Gregory og Milner 2009). Andre påpeger, at fagforeningens betydning er begrænset. I nogle lande står fagforeningen relativt svagt og mangler derfor pondus til at gøre en aktiv indsats på de to områder (Kaiser og Fleckenstein 2009). Manglende interesse for at fremme fx ligelønstiltag fremhæves ligeledes i danske studier som en vigtig forklaring for fagforeningens begrænsede betydning (Andersen og Bloksgaard 2004; Holt og Larsen
2011). Indenfor litteraturen generelt fremhæves især mandsdominerede fagforeninger som inaktive, da ligeløn og balanceproblemer associeres med kvinder og dermed harmonerer dårligt med den maskuline kultur, som præger mandsdominerede fagforeninger og arbejdspladser (Gregory og Milner 2009). Andre påpeger, at $\mathrm{fx}$ ligeløn fylder relativt lidt uanset kønsfordelingen på arbejdspladserne og tilstedeværelsen af en TR, idet ligeløn betragtes som irrelevant af TR, medarbejderne og ledelsen (Holt 2012).

Med henblik på at analysere ligeløns- og familie-arbejdslivstiltag på danske arbejdspladser, trækkes der her på Gregory og Milners (2009) tre 'opportunity structures', som beskriver de overordnede rammer, der har betydning for parternes, herunder især TR's, muligheder for at tage familie-arbejdslivstiltag op lokalt. Selvom ligeløn ikke er omdrejningspunktet i Gregory og Milners analyser, anvendes deres 'opportunity structures' også i analysen af lokale ligelønstiltag, idet nogle af de samme forhold må formodes at gøre sig gældende. Her følger en forklaring af de tre 'opportunity structures':

- Ligestillingspolitik indbefatter, dels hvordan fx familie-arbejdsliv og ligeløn italesættes og promoveres af regeringen og de centrale parter, dels kønsfordelingen indenfor fagforeningen og blandt fagforeningsforhandlere som fx TR. Gregory og Milner inddrager ikke kønsfordelingen på arbejdspladsen i deres model. Men fx Kaiser og Fleckenstein (2009) viser, at det også har betydning for udviklingen af lokale ligeløns- og familie-arbejdslivstiltag. I Danmark er arbejdsmarkedet stærkt kønsopdelt og især de kvindedominerede private arbejdspladser er ofte indenfor service, detail og administration. Det er områder hvor overenskomsten ofte fordrer individuelle frem for kollektive lokalforhandlinger, hvilket indirekte kan begrænse TR's forhandlingsrum. Derimod har de mandsdominere- 
de arbejdspladser, som ofte er indenfor industrien og bygge/anlægssektoren, stærke traditioner for kollektive lokalforhandlinger (HK 2010; Ilsø 2011). Det antages derfor, at kvindedominerede arbejdspladser og virksomheder med en kvindelig TR i højere grad drøfter og forhandler tiltag om ligeløn og familie-arbejdslivsbalancer lokalt, dels fordi det er mere legitimt at tage disse emner op, dels pga. et større pres fra medarbejderne. Omvendt kan det begrænsede forhandlingsråderum på de kvindedominerede arbejdspladser gøre det sværere at forhandle lokalaftaler, mens de lange traditioner på de mandsdominerede arbejdspladser kan lette sådanne forhandlinger.

\section{- Regulering af ligeløns- og familie-arbejds-} livstiltag er bestemmende for, hvordan disse emner håndteres på virksomhederne. Gregory og Milner fokuserer primært på reguleringen af arbejdstid, men den 'opportunity structure' kan med fordel udbygges til også at omfatte reguleringen af løn og arbejdsvilkår mere generelt og herunder fx ligeløn og familie-arbejdsliv, da disse emner ligesom arbejdstid reguleres forskelligt (Williamson 2011). I Danmark er arbejdsmarkedet relativt gennemreguleret via kollektive overenskomster og lovgivning, og det gælder også i forhold til ligeløn og familie-arbejdslivsforhold, som både lov- og aftalereguleres. Der er derfor relativt vide rammer for, at parterne lokalt kan drøfte og forhandle disse emner især på arbejdspladser med tradition for lokalforhandling (Borchorst og Jørgensen 2010). Det forventes derfor, at sådanne debatter og forhandlinger vil være mere udbredt på arbejdspladser med tradition for lokalforhandling, end på arbejdsplader uden sådanne traditioner, da rammerne giver et vist forhandlingsråderum. Omvendt kan netop det gennemregulerede danske arbejdsmarked være med til at begrænse lokale ligeløns- og familie-arbejdslivstiltag, da de centrale overenskomster og lovgivningen allerede i vid udstrækning regulerer de to områder.
- Forboldet mellem TR og arbejdsgivere på virksomhederne sætter også nogle rammer, som begrænser eller fremmer drøftelser og aftaler om ligeløn og familie/arbejdslivsbalancer. At forhandlingskulturen i Danmark præges af konsensus og samarbejdsvilje frem for konflikt forventes at have positiv indflydelse på udviklingen af den type tiltag lokalt (Gregory og Milner 2009; Due og Madsen 2008).

Valget af Gregory og Milners 'opportunity structures' skyldes, at de tager højde for en række forskellige eksterne faktorer eller rammer, som kan fremme eller begrænse udviklingen af tiltag om ligeløn og familiearbejdsliv på virksomhederne (Ravenswood og Markey 2011). Rammerne er dermed bestemmende for, om de centrale parters seneste tiltag herom slår igennem på virksomhederne. Nogle rammer kan dog have større betydning end andre, selvom Gregory og Milner ikke foretager en sådan differentiering. Ikke desto mindre er det i sidste instans op til parterne lokalt, om de vil udnytte de forskellige 'opportunity structures' til at sætte skub i familie/arbejdslivsog ligelønsdebatten. En anvendelse af deres analyseramme i dansk arbejdsmarkedskontekst kan endvidere styrke dens brugbarhed som analytisk værktøj i lande med andre arbejdsmarkedstraditioner.

\section{DATASÆT}

I artiklen trækkes der på data fra en TR-undersøgelse fra 2010 (Larsen et al 2010). Undersøgelsen er finansieret af LO og er en spørgeskemaundersøgelse med tillidsrepræsentanter fra 15 LO-forbund, som belyser deres arbejdsvilkår anno 2010. I undersøgelsen indgår spørgsmål om kønsfordelingen på arbejdspladserne, TR's drøftelser med kolleger og ledelsen om ligeløn og familie-arbejdslivsforhold samt lokalaftaler herom. Vi fik svar fra $7877 \mathrm{TR}$ - svarende til en svarprocent på 48\%. Data blev herefter renset og vagtet i henhold til forbunde- 
TABEL 1: OversigT FOR ANVENDTE DATA (\%)

Arbejds-Pladsen TR-kvinde TR-mand Har lokalaftaler indenfor OK

Flest mænd

Flest kvinder

Ca. lige mange

\begin{abstract}
65
\end{abstract}
17

18

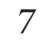

79

47
93

21

54
76

56

61 nes størrelse for at undgå at små forbund blev overrepresenteret i datamaterialet.

I artiklen anvendes data fra den private sektor - svarende til 3275 TR. Blandt dem kender 2\% af TR ikke kønsfordelingen på arbejdspladsen, mens $17 \%$ er på arbejdspladser med flest kvinder, 65\% på arbejdspladser med flest mænd og 18\% på arbejdspladser med ca. lige mange mænd og kvinder. Kvindedominerede/mandsdominerede arbejdspladser defineres som arbejdspladser, hvor det ene køn udgør 75\% eller flere af de ansatte. Endelig udgør arbejdspladser med omtrent lige mange mænd og kvinder den tredje gruppe. Tabel 1 giver en oversigt af de anvendte data.

På kvindedominerede arbejdspladser, er der som oftest en kvindelig TR. De mandlige TR'ere dominerer arbejdspladser med flest mænd. Fordelingen er mere ligelig, når kønsfordelingen blandt medarbejderne er ligelig. Der forhandles endvidere lokalt på de fleste arbejdspladser, selvom lokalforhandlinger er mere udbredt på mandsdominerede arbejdspladser, hvilket kan have betydning for udviklingen af lokale ligeløns- og familie-arbejdslivstiltag.

Dataene anvendes til at belyse, om ligeløn og familie-arbejdslivsforhold drøftes og forhandles på private arbejdspladser. Ligeløn forstås her som kønsmæssig ligeløn, og selvom der i undersøgelsen ikke specifikt er spurgt ind til, hvad ligelønsdiskussionerne og aftalerne konkret dækker over, viser andre undersøgelser, at de ofte omfatter fx ligelønsredegørelser og retningslinjer for fordeling af løntillæg (Holt og Larsen 2011). Familie-arbejdslivstiltag inkluderer de ar- bejdsrelaterede stresspolitikker, plejeorlov, fuld løn under fædre- og forældreorlov, barnets anden eller flere sygedage, flekstidsordninger, mulighed for at arbejde hjemme eller på deltid. Andre tiltag som ferie, fritvalgsordninger og seniorpolitikker analyseres ikke.

\section{LIGELØN}

Dataene viser, at ligeløn fylder relativt lidt på danske arbejdspladser sammenlignet med andre emner. På en liste over emner, som TR drøfter med kolleger og ledelsen, figurerer ligeløn i bunden som nummer 28 ud af 28 mulige emner (Larsen et al 2010). Så selvom ligeløn har været et centralt tema for især fagforeningerne under de seneste overenskomstforhandlinger, er debatten $i k$ $k e$ slået igennem på virksomhedsplan. Rammerne for lokalforhandling har kun begrænset betydning for, om TR drøfter ligeløn og udnytter mulighederne for at indgå aftaler herom. Hver femte TR på såvel arbejdspladser med tradition for lokalforhandling som dem uden lokalaftaler har debatteret ligeløn. Og selvom 70\% af tillidsrepræsentanterne er på arbejdspladser med tradition for lokalforhandlinger, er det kun $3 \%$, som har udnyttet den 'opportunity structure' til at forhandle ligeløn. De gunstige rammebetingelser, i form af lokalforhandling og de centrale parters ligelønstiltag, udnyttes dermed kun i begrænset omfang lokalt til at fremme ligeløn. Ikke desto mindre har hver femte TR haft ligeløn på dagsordenen, og enkelte steder er debatterne endt med konkrete aftaler. 
TABEL 2: TR SOM HAR DRØFTET OG INDGÅET AFTALER OM LIGELØN

IHT. KØNSFORDELINGEN PÅ PRIVATE ARBEJDSPLADSER (\%)

Drøftet med kolleger og ledelsen

Flest mænd

Flest kvinder

Ca. lige mange
15

24

30
Indgået lokalaftaler

2

2

3

$\mathrm{n}=3215, \mathrm{p}=0,000\left(\mathrm{Chi}^{2}\right)$

- Hvor drøftes og forhandles ligeløn: Ligeløn har tiltrukket størst opmærksomhed på arbejdspladser med lige mange mænd og kvinder, og det drejer sig især om arbejdspladser indenfor produktion/samlebånd, handel, IT og teknik. Drøftelserne udmøntes dog sjældent - ligesom på mange kvinde- og mandsdominerede arbejdspladser - i konkrete aftaler:

Dobbelt så mange arbejdspladser med lige mange mænd og kvinder har debatteret ligeløn sammenlignet med de mandsdominerede arbejdspladser, hvor 15\% af TR især indenfor handel, kontor og administration har drøftet ligeløn. Også på de kvindedominerede arbejdspladser tiltrækker ligeløn mindre opmærksomhed. Lokalaftaler om ligeløn indgås dog ikke i større udstrækning på arbejdspladser, hvor kvinder udgør en større andel af medarbejderstaben. Det tyder derfor på, at nok har andelen af kvinder betydning for ligelønsdebatten som antaget $\mathrm{i}$ analyserammen, men det synes ikke at være bestemmende for, om parterne indgår aftaler om ligeløn. Andre studier fremhæver også, at ligeløn uanset kønsfordelingen på arbejdspladsen sjældent er del af lokalforhandlingerne, selvom det er aftalestof (Andersen og Bloksgaard 2004; Holt 2012). Ifølge Holt og Larsen (2011) skyldes det, at ligeløn ofte anses som irrelevant blandt de involverede parter. Andre fremhæver, at lønmidlerne ofte er begrænsede, hvorfor der reelt ikke er meget at forhandle lokalt ikke kun ift. aftaler om ligeløn, men også løn mere generelt (Andersen og Bloksgaard 2004). Dette kan tilsammen med det faktum, at ligelønsområdet er relativt gennemreguleret fra centralt plan, forklare de relativt få lokalaftaler om ligeløn. Ikke desto mindre vidner tallene om, at det kan være mere legitimt at drøfte ligeløn på arbejdspladser med mange kvinder, hvilket er i tråd med den første 'opportunity structure' om ligelønspolitik. Det kan også være fordi, at der netop på disse arbejdspladser er uligelønsproblemer.

- Initiativtageren: På arbejdspladser, hvor ligeløn drøftes og forhandles, er det lidt oftere de kvindelige end mandlige TR, som tager initiativet. Hver fjerde kvindelige TR mod $18 \%$ af de mandlige TR initierer ligelønsdebatten. Der er dog lidt flere mandlige TR, som samlet set har forhandlet aftaler med ledelsen om ligeløn. Ser vi specifikt på arbejdspladser med hhv. flest mænd, flest kvinder og lige mange mænd og kvinder nuanceres billedet.

Mandlige TR står især bag ligelønstiltagene på arbejdspladser med lige mange mænd og kvinder, mens mandlige og kvindelige TR i lige stort omfang drøfter og forhandler ligeløn på de kvindedominerede arbejdspladser. Derimod er det primært de kvindelige TR, som debatterer ligeløn på de mandsdominerede arbejdspladser, mens lidt flere af deres mandlige kolleger indgår aftaler herom. Tillidsrepræsentantens køn synes dermed at spille en mindre rolle end 
TABEL 3: KVINDELIGE OG MANDLIGE TR, SOM HAR DRØFTET OG INDGÅET AFTALER OM LIGELØN IHT. KØNSFORDELINGEN PÅ PRIVATE ARBEJDSPLADSER (\%)

Drøftet med kolleger eller ledelsen

TR-mand TR-kvinde

Flest mænd

Flest kvinder

Ca. lige mange
13

22 *

35 **
33

25 *

25 **

\section{Lokalaftaler}

TR-mand TR-kvinde

3

2

1

2

4

$\mathrm{n}=3214 \mathrm{p}=00,000,{ }^{*} \mathrm{p}=0,108,{ }^{*} \mathrm{p}=0,006\left(\mathrm{Chi}^{2}\right)$

antaget af Gregory og Milner. Såvel mandlige som kvindelige TR synes at udnytte den 'opportunity structure', som flere kvinder blandt medarbejderstaben skaber, til at drøfte og forhandle ligeløn lokalt.

- Forholdet mellem TR og ledelsen: Dette har også en vis betydning. Således har hver femte TR med et godt forhold til ledelsen haft ligeløn op og vende $\bmod 15 \%$ med et anspændt forhold til ledelsen. Forskellene er mindre markante, når det gxlder lokalaftaler. 5\% af TR med et godt forhold til ledelsen har forhandlet aftaler $\bmod 4 \%$, som ikke er i den situation. Betydningen af TR's forhold til ledelsen og dermed den tredje af Gregory og Milners 'opportunity structure' understreges yderligere, når graden af tillid til ledelsen og ligelønstiltagene på kvindeog mandsdominerede arbejdspladser sammenholdes. Således stiger ligelønstiltagene proportionalt med graden af tillid på arbejdspladserne, uanset kønsfordelingen på arbejdspladserne.

\section{FAMILIE-ARBEJDSLIVSBALANCER}

Balance mellem familie-arbejdsliv figurerer lidt højere på dagsordenen end ligeløn. $44 \%$ af tillidsrepræsentanterne har drøftet familie-arbejdslivsbalancer med kolleger og ledelsen, og relativt mange har også forhandlet aftaler, der sigter på at lette lønmodtageres familie-arbejdsliv. Samlet set vedrører $35 \%$ af lokalaftalerne, der er forhandlet indenfor rammerne af overenskomsten, familie-arbejdslivsemner. Familie-arbejdslivsforhold er dermed et af de temaer, som flest TR har lavet aftaler om - kun overgået af aftaler om arbejdstid og løn. De centrale parters prioritering af familie-arbejdslivsområdet genspejles dermed ofte $-\mathrm{i}$ modsætning til ligeløn - i lokalforhandlingerne. Her synes rammerne for lokalforhandling at gøre en forskel. Lidt flere TR, som har mulighed for at forhandle lokalt, har drøftet familie-arbejdslivsforhold med kolleger og ledelsen end TR på arbejdspladser uden tradition for lokalforhandling. At relativt mange TR endvidere indgår aftaler om familie-arbejdsliv tyder på, at den 'opportunity structure' som lokalforhandling giver, i større udstrækning har haft positiv betydning for udviklingen af lokale familie-arbejdslivstiltag end ligelønsinitiativerne.

\section{- Hvor droftes og forhandles familie-arbejds-} livsforhold: Familie-arbejdsliv optager især parterne på arbejdspladser med mange kvinder. $42 \%$ af tillidsrepræsentanterne på mandsdominerede arbejdspladser drøfter familie/arbejdslivsforhold mod hver anden på arbejdspladser med flest kvinder eller lige mange mænd og kvinder.

Aftaler, som sigter mod at lette lønmodtageres familie-arbejdslivsbalance, er også mindre udbredt på mandsdominerede ar- 
TABEL 4: TR SOM HAR DRØFTET OG INDGÅET AFTALER OM FAMILIE-ARBEJDSLIV IHT. KØNSFORDELINGEN PÅ PRIVATE ARBEJDSPLADSER (\%)

Drøftet med kolleger og ledelsen

\section{Flest mænd}

Flest kvinder

Ca. lige mange
42

49

49

\section{Indgået lokalaftaler}

45

$\mathrm{n}=3216 \mathrm{p}=0,000\left(\mathrm{Chi}^{2}\right)$

bejdspladser. $29 \%$ af tillidsrepræsentanterne på den type arbejdspladser har indgået aftaler herom mod $45 \%$ på arbejdspladser med lige mange mænd og kvinder og $42 \%$ af de kvindedominerede arbejdspladser. I de fleste tilfælde omhandler aftalerne flekstid. 4\% af arbejdspladserne har aftaler om arbejdsrelateret stress og deltid, og endnu færre har aftaler om betalt fædre- og forældreorlov, plejeorlov, hjemmearbejde og barnets anden eller flere sygedage. Ordninger om betalt orlov og hjemmearbejdsmuligheder tilbydes primært på arbejdspladser med lige mange mænd og kvinder. Derimod forhandles flekstid, arbejdsrelateret stress, deltid og barnets anden eller flere sygedage på lidt flere kvindedominerede arbejdspladser end arbejdspladser med færre kvinder blandt medarbejderne. Kønsfordelingen på virksomhederne synes dermed at have en vis betydning, hvilket antyder, at det kan være mere legitimt at drøfte og forhandle familie-arbejdslivstiltag på arbejdspladser med mange kvinder - resultater som er i tråd med den 'opportunity structure' om ligestillingspolitik.

- Initiativtager: Ser vi på, hvem der står bag familie-arbejdslivstiltagene, fremgår det, at næsten lige mange kvindelige og mandlige TR samlet set står i spidsen for sådanne tiltag. Men der er forskelle arbejdspladserne imellem. Den mandlige TR på arbejdspladser med mange kvinder synes især at have øje for familie-arbejdslivsproblematikken. De har i langt større grad indgået aftaler for at lette kollegernes familie-arbejdsliv ikke kun sammenlignet med de kvindelige TR

TABEL 5: KVINDELIGE OG MANDLIGE TR, SOM HAR DRØFTET OG INDGÅET AFTALER OM FAMILIE-ARBEJDSLIV IHT. KØNSFORDELINGEN PÅ PRIVATE ARBEJDSPLADSER (\%)

\section{Drøftet med kolleger eller ledelsen}

TR-mand

42 *

49 * *

50

TR-kvinde
$36^{*}$

49 * *

47

\section{Flest mænd}

Flest kvinder

Ca. lige mange

\section{Lokalaftaler}

TR-mand TR-kvinde

30 27

59

36

51

36 
på den type arbejdspladser, men også ifht. mandlige TR på mandsdominerede arbejdspladser.

På kvindedominerede arbejdspladser er familie-arbejdslivsdebatten blevet udmøntet i konkrete aftaler blandt $59 \%$ af de mandlige mod $36 \%$ af de kvindelige TR. Forskellene er mindre markante på de mandsdominerede arbejdspladser, når det gxlder konkrete aftaler, men i forhold til familie-arbejdslivsdebatten tager især de mandlige TR initiativet. Mulighederne for lokalforhandling spiller dog en vis rolle i den sammenhæng. Flere mandlige TR er på arbejdspladser med tradition for lokalforhandling uanset kønsfordelingen på den enkelte arbejdsplads. De har derfor større mulighed for at omsætte drøftelserne til konkrete tiltag. Ikke desto mindre tyder det på, at det ikke nødvendigvis behøver at være en kvindelig TR bag roret som argumenteret af Gregory og Milner for at fremme familie-arbejdslivstiltag. Såvel mandlige som kvindelige TR synes at udnytte den første 'opportunity structure', som flere kvinder blandt medarbejderne skaber mht. til at drøfte og indgå aftaler om familie-arbejdsliv.

- Forholdet mellem TR og ledelsen: Gregory og Milners tredje 'opportunity structure' forholdet mellem TR og ledelsen - har ligeledes betydning for udviklingen af konkrete familie-arbejdslivsaftaler, mens drøftelserne parterne imellem synes uanfegtet. $45 \%$ af TR med et gensidigt tillidsforhold til ledelsen har drøftet familie-arbejdsliv med kolleger og ledelsen mod $44 \%$ uden sådanne relationer. Derimod har lidt flere TR med et godt forhold til ledelsen forhandlet aftaler (36\%) mod hver fjerde, hvor forholdet til ledelsen er helt eller delvist anstrengt. Faktisk stiger andelen af aftaler - ligesom for ligeløn - proportionalt med graden af tillid på arbejdspladserne. Og ser vi specifikt på typer af arbejdspladser, gør det sig også gældende på arbejdspladser med hhv. flest mænd og lige mange mænd og kvinder. Sammenhængen er knap så entydig på de kvindedominerede arbejdspladser, hvor en relativ stor gruppe TR har formået at indgå familie-arbejdslivsaftaler trods et anstrengt forhold til ledelsen.

\section{KONKLUSION}

På private arbejdspladser har parterne i varierende grad iværksat initiativer om ligeløn og familie-arbejdsliv og dermed indirekte omsat de centrale parters forskellige tiltag herom til praksis. Der er dog store forskelle på, hvad der optager parterne lokalt. Mens en række TR har drøftet, forhandlet og indgået aftaler for at lette lønmodtageres familie-arbejdslivsbalance, figurerer ligeløn i bunden af virksomhedernes dagsorden. De centrale parters familie-arbejdslivsinitiativer synes dermed i større omfang at være slået igennem på virksomhederne end deres ligelønstiltag. Og det selvom begge emner har fyldt relativt meget under de seneste års overenskomstforhandlinger.

Ses der på, hvor på arbejdsmarkedet ligeløn og familie-arbejdslivsforhold drøftes og forhandles, er der variationer ikke kun mellem kvinde- og mandsdominerede arbejdspladser, men også blandt arbejdspladser med forskellige traditioner for lokalforhandling og relationer parterne imellem.

Analysen viste, at under rammen for ligestillingspolitik spiller de centrale parters ligeløns- og familiearbejdslivstiltag en mindre rolle. Til gengæld er kønsfordelingen på arbejdspladsen og blandt TR af betydning - og på en overraskende måde. Det er især arbejdspladser med lige mange mænd og kvinder, hvor ligeløn og familiearbejdsliv optager parterne; og det er ofte de mandlige TR, som drøfter og især indgår aftaler herom. Flere mandlige end kvindelige TR står også i spidsen for ligeløns- og familie-arbejdslivsaftalerne på de kvindedominerede arbejdspladser, mens deres kvindelige kolleger oftere tager den type diskussioner. Resultaterne indikerer, at både kvindelige og mandlige TR udnytter den 'op- 
portunity structure' som flere kvinder blandt medarbejderne skaber for at fremme ligeløns- og familie-arbejdslivstiltag. Dette sætter spørgsmålstegn ved antagelsen om, at progression indenfor disse områder primært drives af kvindelige TR. Derimod bekræfter resultaterne anden litteratur mht. betydningen af kønsfordelingen blandt medarbejderne for udviklingen af sådanne tiltag (Ravenswood og Markey 2011). At lidt flere mandlige TR står bag lokalaftaler kan skyldes, at de i højere grad er på arbejdspladser med tradition for lokalforhandling og dermed har mulighed for at forhandle lokalaftaler. Forskellene kunne også skyldes forskellige forventninger til hhv. kvindelige og mandlige TR. Således viser Andersen og Bloksgaard (2004), at tildeling af løntillæg ofte er baseret på ledelsens opfattelse af mænd og kvinder frem for myten om, at kvinder er dårligere forhandlere end mænd. Dette kunne også gøre sig gældende $\mathrm{i}$ forhold til kvindelige og mandlige TR, hvor ledelsen kan have en anden opfattelse af de mandlige TR og lader det påvirke forhandlingsforløbet.

At familie-arbejdsliv og ligeløn er aftalestof, og dermed i varierende grad er lagt ud til lokalforhandling, er ligeledes bestemmende for, hvordan disse emner drøftes og forhandles lokalt. Aftaler herom er udelukkende indgået på arbejdspladser med tradition for lokalforhandling. Men parterne har primært udnyttet den form for 'opportunity structure' til at forhandle aftaler om familie-arbejdsliv frem for ligeløn. Markant flere arbejdspladser med mulighed for lo- $^{-}$ kalforhandling har endvidere drøftet familie-arbejdsliv, mens forskellene er mindre markante mht. ligeløn. Dette vidner om, at selvom der er relativt vide rammer for lokalforhandling, er det langt fra alle TR, som udnytter muligheden til at fremme ligeløn og familie/arbejdslivsforholdene. At ligeløn tiltrækker mindre opmærksomhed end familie-arbejdsliv kan skyldes, dels at emnet betragtes som irrelevant af de involverede parter, dels at lønmidlerne ofte er begrænsede og dermed indskrænker de reelle ligelønsforhandlinger (Holt og Larsen 2011; Andersen og Bloksgaard 2004). Desuden begrænser ligelønstiltagene sig ofte til forhandlinger om retningslinjer for fordeling af lønmidler, mens familie-arbejdslivsforhold dækker over et bredere spektrum af mulige emner, hvilket også kan have betydning for udviklingen af lokale tiltag. Derudover synes ligelønsområdet også at være mere gennemreguleret fra centralt plan end familie-arbejdslivsområdet. Lovgivningen og nogle områdeoverenskomster giver $\mathrm{fx}$ ikke ret til fleksibel arbejdstid og fuld løn under børns sygdom, men overlader det til parterne lokalt at forhandle herom. Ikke desto mindre indikerer resultaterne, at det langt hen ad vejen er parterne lokalt, som afgør, hvorvidt de vil gøre en aktiv indsats.

Den tredje 'opportunity structure' - forholdet mellem TR og ledelsen - har ligeledes vital betydning. På arbejdspladser, hvor forholdet er præget af gensidig tillid, har man i højere grad drøftet og indgået aftaler om ligeløn og familie-arbejdsliv, mens det i mindre udstrækning er gxldende på arbejdspladser med mere anspændte relationer parterne i mellem. Dette gælder især ift. de her undersøgte områder, mens forskellene er minimale, når vi mere generelt sammenligner arbejdspladser, hvor TR har forhandlet lokalaftaler med deres samarbejdsrelationer med ledelsen. TR som har et godt forhold til ledelsen er således ikke mere tilbøjelige til at forhandle lokalaftaler med ledelsen generelt set end deres kolleger, som har et anspændt forhold til ledelsen (Larsen et al 2010).

Alt i alt viser resultaterne, at det primært er de centrale parters familie-arbejdslivstiltag, som er slået igennem på virksomhedsplan, mens ligelønsinitiativer ofte halter bagefter. $\mathrm{Og}$ det selvom rammebetingelserne - mulighederne for lokalforhandling, relationerne mellem parterne samt kønsfordelingen på arbejdspladserne og blandt tillidsrepræsentanterne - er relativt gunstige. 


\section{LITTERATUR}

- Andersen, Pernille Tanggaard og Bloksgaard, Lotte (2004): Når køn forbandler løn, LO, København.

- Borchhorst, Anette og Jørgensen, Henning (2010): Fagbevægelsen og ligeløn, i: Tidsskrift for Arbejdsliv, 12: 4, 10-28.

- Due, Jesper og Madsen, Jørgen Steen (2008):

The Danish Model of Industrial Relations, i: Journal of Industrial Relations, 50:2, 513-529.

- Emerek, Ruth og Bloksgaard, Lotte (2010): Familievenlighed og/eller tilstedeværelse, i: Tidsskrift for Arbejdsliv, 12: 4, 46-61.

. FA (2012): FAMagasinet, FA, København.

- Gregory, Abigail og Milner, Susan (2009): Trade unions and Work-life balance, i: British Journal of Industrial Relations, 47:1, 122-46.

- HK- Handel (2010): Overenskomstbestemmelser vedr. barsel $i \mathrm{HK}, \mathrm{HK}$, København.

- Holt, Helle (2012): Lokal løn på kommunale arbejdsplader, SFI, København, 12:18.

- Holt, Helle og Larsen, Mona (2011): Konsopdelt lønstatistik og redegørelse om ligeløn, SFI, København 11:48.

- Ilsø, Anna (2011): The Flip Side of Organized Decentralization, i: British Journal of Industrial Relations,

http://onlinelibrary.wiley.com/doi/10.1111/j.14678543.2011.00875.x/pdf.

- Kaiser, Martin Seeleib og Fleckenstein, Timo (2009): The political economy of occupational family policies, i: British Journal of Industrial Relations, 47:4, 741-64.

- Larsen, Trine Pernille og Navrbjerg, Steen Erik og Johansen, Mikkel (2010): Tillidsrepresentanten og arbejdspladsen, LO, København.
- Ministeriet for Ligestilling og Kirke (2012): Redegorelse perspektiv og handlingsplan, Regeringen, København.

- Ravenswood, Katherine og Markey, Raymond. (2011): The role of unions in achieving a familyfriendly workplace, i: Journal of Industrial Relations, 53:4, 486-503.

- Rigby, Mike og Smith, Fiona O’Brien (2010): Trade union interventions in work-life balance, i: Work, Employment and Society, 24:2, 203-20. -Williamson, Sue (2011): Gendering the Bricks and Mortar, i: Journal of Industrial Relations, 54:2, 147-63.

\section{SUMMARY}

This paper explores to what extent the government and social partners' recent work-life balance and equal pay initiatives are discussed and negotiated in Danish workplaces. It argues that whilst work-life balance issues often are at the top of social partners' bargaining agenda at company level, equal pay typically figures at the very bottom. In addition, these issues are more likely to be up for local bargaining in companies where women constitute one in two or more of the employees - and in such companies it is interestingly often the male shop steward who takes the lead.

Trine P. Larsen, lektor

FAOS, Københavns Universitet 